\title{
Kiyoku, tadashiku, utsukushiku: Takarazuka Revue and the project of identity (re-)solidification
}

\author{
MARIA GRĂJDIAN
}

\begin{abstract}
Throughout Japan's ambitions to redefine superpower as cultural issue, the popular all-female musical theater Takarazuka Revue has been a faithful companion. Concurrently anachronistic in its gender exhibition and progressive in its performance practice, Takarazuka Revue has been typically reconstructing, since 1913, asymmetric interactions between identity and alterity, model and copy, as well as male and female - all wrapped up in spectacular tunes, magnificent costumes and luxurious scenery. While focusing on the postwar period, that is since the re-opening of the Grand Theater in Takarazuka in 1946, and on the tension between the androgynously charismatic otokoyaku figures [i.e., female interpreters of male roles in the Takarazuka Revue] and the apparently conformist and submissive musumeyaku figures [i.e., female interpreters of female roles in the Takarazuka Revue], it is this paper's goal to underline some of Takarazuka Revue's strategies to construct, develop, propagate and eventually implement its - and by extension: the Japanese historical worldview by means of a new form of cultural imperialism, namely love as ideological base and an aesthetic superstructure of latemodern identity. This article quests to reveal the core element within the project of identity (re-)solidification proposed by the Takarazuka Revue: an emerging form of cultural awareness based on tenderness as existential attitude.
\end{abstract}

Keywords: Takarazuka Revue; otokoyaku; musumeyaku; Kobayashi Ichizō; Zygmunt Bauman; identity paradigms; tenderness. 
清く、正しく、美しく：宝塚歌劇とアイデンティティの(再) 固定
化プロジェクト マリア・グラジデイアン

超大国の定義を文化発信力の問題として再定義しようとする日本の潮 流の中で、大衆娛楽である宝塚歌劇は常にその流れに従ってきた。宝 塚歌劇は、いまでは時代おくれな女性歌劇でありながら、1913年の結 成以来、進歩的なパフォーマンスで、アイデンティティと他性、モデ ルとコピー、男と女など非対称な関係から生じる相互作用を劇的な歌 曲、豪華な衣装、そして華やかな舞台で包み込みながら再現してきた のである。

本稿は、戦後、すなわち1946年の宝塚大劇場の再開以降における宝塚 歌劇のアンドロギュネス的カリスマである男役と一見協調的で従順な 娘役とが醸し出す緊張感に焦点をあてながら、宝塚歌劇の構成、発展、 宣伝 の戦略を取り上げる。

そして宝塚歌劇団が、いかにして、新しいタイプの文化的帝国主義、 すなわちイデオロギー的基盤および後期近代のアイデンティティの美 的上部構造としての「愛」を用いて、自らの（また幅広い意味において日 本の) 歴史的世界観を構築し、作り上げ、広めようとしたのか、その戦 略について検討する。本稿は、宝塚歌劇団によるアイデンティティ (再) 固定化のプロジェクトの核心、すなわち存在態度としての優しさ (tenderness)に基づく新しい文化意識を明らかにするものである。

\section{Introduction: The orchestration of humanity}

Nowadays, it is an open secret that Japan is redefining superpower ${ }^{1}-$ though as cultural issue; a faithful interpreter of its ambitions is the popular all-female musical theater Takarazuka Revue. Concurrently anachronistic in its gender exhibition and progressive in its performance practice, Takarazuka Revue reconstructs in a specific way asymmetric interactions between identity and alterity, challenging traditional concepts such as model and copy, all wrapped up in spectacular tunes, magnificent costumes and luxurious scenery. While focusing on the postwar period, since the re-opening of the Grand Theater in Takarazuka in 1946, which marked an unexpected revival in Takarazuka Revue's selforchestration through the increasing lavishness of its performances and the intensified commercialization of its increasingly androgynous otokoyaku figures, the following lines analyze the paradigm shift in Takarazuka Revue's ideological-aesthetic staging of the Japanese contemporary 
mulation of its motto "Kiyoku, tadashiku, utsukushiku" [purity, righteousness, beauty]. This paper underlines some of Takarazuka Revue's strategies to construct, develop and eventually implement its - and by extension: the Japanese - historical worldview by means of a new form of cultural imperialism, ${ }^{2}$ that is, $\operatorname{love}^{3}$ as simultaneously an ideological base and an aesthetic superstructure of late-modern identity. As will be shown, the transition from ethics to aesthetics and from imagination to ideology in the public staging of love reflects Takarazuka Revue's metamorphosis from an insignificant socio-cultural medium to a powerful political-economic message in postwar Japan.

Most academic discussions on Takarazuka Revue tackle the problematic of the androgynous and fascinating otokoyaku figures [i.e., female interpreters ${ }^{4}$ of male roles in the Takarazuka Revue] (see Berlin 1988; Kawasaki 1999; Robertson 1998; Stickland 2008). However, this paper focuses on the tension between the androgynously charismatic otokoyaku figures and the apparently conformist and submissive $m u$ sumeyaku figures [i.e., female interpreters of female roles in the Takarazuka Revue] with the goal to reveal some strategic assertions at the very core of the project of identity (re-)solidification proposed by Takarazuka Revue through the stature of its actresses ${ }^{5}$ as embodied by otokoyaku and musumeyaku: on the one hand, there is extroversion and self-confidence; on the other hand, there is cuteness and fragility.

Takarazuka Revue's self-definition as a "dream world of love" stated and displayed publicly as well as its stress of courage and friendship, victory and endeavor for the insiders will lead the focus on disclosing the way cultural matters are reflecting and converting, and then again, are being reflected and converted by social, economic and political factors. The analysis is pursued on two levels: (i) the intrinsic level referring to the form and contents of the performances; (ii) the extrinsic level connected with the cultural, social, economic and politic dimensions of the Takarazuka Revue as historical phenomenon in the context of the Japanese modernity and of the modern world at large. Zygmunt Bauman's (2000: 28-35) concept of liquid modernity constitutes the foundation of the following analyses which also employ ideology ${ }^{6}$ and aesthetics ${ }^{7}$ as well as their dialectic relation in defining and constituting identity paradigms. The conscious and highly stylized exhibition and manipulation of love as "atmospheres" (Böhme 1995: 28-35) leads in Takarazuka Revue to new forms of existential orientation that challenge the traditional view of theater as an entertainment space and is reminiscent of the original meaning of the word "scene" - from the original Greek word skiní, meaning cottage or temple as "space" for the gods to materialize (Böhme 2001: 19-23). It denotes a space which is separated from the real world and which protects people from real 
happenings; it designs parallel universes to the experienced reality and stimulates these as possible alternatives. In order to illustrate these statements, I shall proceed in three steps: (i) by placing identity paradigms as represented by postwar Takarazuka Revue in a historical context; (ii) by elucidating the two main figures of Takarazuka Revue the androgynously ambivalent and charismatic otokoyaku and the apparently conformist and impersonal musumeyaku - from this new historical perspective; and (iii), in the conclusion, by examining this emerging identity paradigm as a new form of cultural awareness based on tenderness as an existential attitude. Otokoyaku and musumeyaku are regarded intrinsically, in their on-stage embedding within performances, and extrinsically, as social actors in the public sphere subject to limits, regulations and circumstances generated both by the quotidian Japanese society and by the imaginations and expectations of Takarazuka Revue's specific environment (especially fans' and administrators' prescriptions).

Since its foundation in 1913 by Kobayashi Ichizō, ${ }^{8}$ Takarazuka Revue has become a symbol of modern Japanese entertainment, consumption and the popular culture industry (Kawasaki 2005: 67). Though an imported genre from the West, mainly influenced by the French revue since the 1920s and additionally by the American musical since the 1960s, Takarazuka Revue actually continues the Japanese cross gender theatrical tradition emblematically represented by Nō and Kabuki with their highly stylized female impersonation, while reversing the positions of representation through the female interpreter of male roles, impersonations that here, likewise, are highly stylized. Yet, Takarazuka Revue functions as the ideological and aesthetic base of several genres of Japanese entertainment culture - both those which have recently been recognized worldwide as global(ized) cultural products such as manga, anime, video games and those which are still deeply locally implemented such as TV dramas, TV shows and the aidoru [idol] phenomenon (Grăjdian 2009: 31). The ideological dimension of Takarazuka Revue's influence upon the domestic popular culture condenses itself in the energy, passion and vitality radiated by most of such products as well as in the denomination of Japanese modern entertainment culture as a long, uninterrupted history of love, peace and courage with focus on friendship, endeavor and victory at least since 1968, that is, the founding year of manga magazine Shonen Jump..$^{9}$ These features are supposed to be related (see Saitō 1996: 45; Watanabe 1999: 142) to Takarazuka Revue's motto "Kiyoku, tadashiku, utsukushiku” [purity, righteousness, beauty]. The aesthetic dimension of Takarazuka Revue's influence on Japanese culture, on the other hand, could be observed in the almost obsessive quest for endlessly long legs and incredibly big 
eyes in Japanese everyday life. ${ }^{10}$ Furthermore, Takarazuka Revue's market-connected characteristics cannot be denied as its relevance rests on its saleability - and yet Takarazuka Revue is simultaneously subjected to unusually strong dialectics. As a local appearance of the early 20th century, Takarazuka Revue contains strong elements belonging to the global market, indeed it continues the Japanese theater tradition of cross gender, but it was imported from the West, and profoundly influenced the domestic entertainment and consumption industry, a part of which has been accepted and recognized worldwide during the last decades - which in turn has metamorphosed in new Western genres of popular culture, only to be perceived and absorbed by the Japanese public world as Western entertainment forms.

\section{The re-invention of identity}

Takarazuka Revue's emergence as part of the Hankyū Railways Company as well as its development along the tumultuous 20th century up to the present are representative elements of a world moving simultaneously centripetally and centrifugally. Constantly, Takarazuka Revue proves the fact that culture is basically the mechanism of a discursive power which manufactures the correlation between social past and individual consciousness not causally, but contingently via historical practices. Due to its function as a subcultural medium tending toward mainstream standards, Takarazuka Revue has drafted, throughout its existence, diagnoses of Japanese society according to which the solid elements of identification entities metamorphose into liquefaction tendencies, only to leave in place unstable (liquid) structures which, in their turn, alternate with insinuating tones of re-solidified identity patterns. The reflection of the Japanese correspondence to what Anderson (1988: 85) calls the "solid, civilized, morally upright bourgeoisie which managed to survive WWII" in performances with concrete reference to classical values and ideals had turned, by the mid-1970s, into an increasingly inscrutable "aquarium of floating, evanescent forms" (Anderson 1988: 86) populated with charismatic, still vaguely unseizable characters, only to be replaced by blockbuster-like performances celebrating the completed instability of identity as a subversive enterprise in a liquid world at large (see Bauman 2000: 28).

\section{1. "Kiyoku, tadashiku, utsukushiku” - three identity paradigms}

Takarazuka Revue's re-opening after the war marked an important paradigm shift in its ideological-aesthetic staging of the Japanese contemporary society and culture according to the re-formulation of its 
motto "Kiyoku, tadashiku, utsukushiku", as it evolved from a moral model before the war to a mirror of society after the war. Taking this view, one notices three stages in Takarazuka Revue's postwar identity design.

In April 1946, the Grand Theater in Takarazuka was re-opened with the permission of SCAP (Supreme Commander for the Allied Powers). ${ }^{11}$ The ceremonious re-opening was celebrated by a Takarazuka Revue-like adaptation of Georges Bizet's opera Carmen (Karumen, 1946) and the performance Haru no odori - ai no yume [Spring dance - the dream of love]. It is during this stage including the culturally relevant late 1950s, 1960s and early 1970s that stress was laid on the plots of the performances such as in Romeo and Juliet (Romio to Jurietto, 1949, based on William Shakespeare's classic tragedy), Gubijin [The beautiful Gu, 1951], Merry widow (Merī uidō, 1956, based on Franz Lehár's original operetta from 1905), Rebyū ovu rebyūzu [Revue of revues, 1961], West Side Story (Uesuto saido monogatari, 1968, based on Leonard Bernstein and Stephen Sondheim's musical from 1957) and Takarazuka Expo '70 (1970). While reflecting the classical values and ideals of the Japanese postwar middle-class transported in various times and spaces, these histories reinforced and consolidated the selfawareness of the emergent average individual. However, in their subtexts, they also announced the dissolution of semantic borders through the artistic processing of the tension between tradition and innovation (Hashimoto 1999: 189; Tsuganesawa 1991: 113). The problem of creatively coping with modes of knowledge and information translation from the "what?" of consumption models to the "how?" of consumption behavior became increasingly obvious during Takarazuka Revue's staging of history - alternative or documented history - which created an aggravating confusion between media and message. This confusion can be tracked down to the original confusion between containers of traditions and bearers of innovations supposed to be included in cultural productions. The distressing relation between media disintegrating into message and innovation being swallowed up into tradition's amalgams continues until the present and is faithfully reflected in Takarazuka Revue's works of the first third of the postwar era (see Castells 1998: 325). At this stage, identity appears as creative dialectics of the individual within a stable socio-cultural conglomerate; the plot, and not the scenery or the characters, is the focus; purity is the predominant feeling. This corresponds, in the era, to the economic reconstruction, to love, courage, endeavor and hope as predominant emotions, to human togetherness as a social pattern and to the increasing awareness on a political level; culturally, the sincerity and vitality of the 1950s, 1960s and 1970s would be unequaled up to the present. 
Introduced in 1974 by the blockbuster The Rose of Versailles (Berusaiyu no bara), Ueda Shinji's Takarazuka Revue-like adaptation of Ikeda Riyoko's eponymous manga (1972-1973), the second stage would last until 1993 - the opening of the New Grand Theater in Takarazuka. In this period of time, Takarazuka Revue reflects the convulsions and disaggregation processes of the Japanese society visible in an increasing liquefaction of identity patterns while concurrently attempting to implement the Japanese way as the right path to follow (tadashiku) due to Japan's economic power. The Rose of Versailles not only marked the beginning of the transition from the solid to the liquefaction stage, but also the moment when Takarazuka Revue simultaneously gained its -ness and lost its raison d'être according to Kobayashi Ichizō (1955: 33-41; see Ueda 1997: 48-51). Starting with Oscar François de Jarjayes, the symbolic main character in The Rose of Versailles, continuing with Scarlett O'Hara from Gone with the Wind (Kaze to tomoni sarinu, 1976, based on Margaret Mitchell's novel from 1936 and strongly influenced by the film version from 1939), and marking a climax with Hikaru Genji from Shin-Genji monogatari [The new tale of Genji, 1981], characters evolved and replaced histories in their hierarchical popularity. Their playful manipulation of values and ideals as well as their noncommittal integration within the framework of the plots and identification modes stand on-stage for the historically emergent disbelief in inherited and as such established existential attitudes. The emergence of individual tensions calls for collisions between the semiotic and the symbolic level of identity construction in Julia Kristeva's (1974: 158) reading of the process, and is reflected in the emblematic figures of Takarazuka Revue's intrinsic and extrinsic world actresses and audiences - during the economically relevant late seventies and the entirety of the eighties. Individuals rather than histories highlight the liquefaction process of their identities while stressing Japanese righteousness as a new attitude mode (see Castells 1998: 338). An important issue in this context is the transition from cute (kawaii) to cool (kakkoii) in an anthropological sense, that is, in Joy Hendry's parlance, the emancipation from being represented by others (in Lacan's words "being the phallus") to itself representing oneself and the others (in Lacan's words "having the phallus"), visible in such performances as $Z a$ reby $\bar{u}$ [The revue, 1977], Andorojenī [The androgyny, 1985] and Za rebyüsukopu [The revuescope, 1987] (see Hendry 2000: 24; Žižek 1989: 118-136). Economically, there is excess, consumerism and surplus as life paradigms, enthusiasm is the predominant emotion, while the individualization of society and cultural self-confidence find their counterpart in political exuberance. 
After this transitional stage, one bounces into what one could call "liquid identity" on the basis of Zygmunt Bauman's conceptualization of late modernity as liquid modernity (Bauman 2000: 37; Grăjdian 2009: 288): From 1993 on up to the present, the aesthetic dimension of humanity as articulated in Gernot Böhme's (1995: 28-35) analysis of the atmosphere concept emerges in Takarazuka Revue's performances and affirms the beauty of the world (utsukushiku) as core of the liquid identity paradigm - that is, unstable in its shape and contents. Neither histories nor characters dictate the market, but performances: namely, blockbusters to accompany the socio-politically relevant 1990s-2000s (Kawasaki 2005: 14-15). The box-office turns into the focus and beauty develops into a new zeitgeist. Confronted with an increasing socio-cultural fragmentation within the liquid spectrum, the Takarazuka Revue blockbusters of the last 17 years deal with the anonymization of the masses and the alienation of the individuals within those masses. There is a permanent disenchantment process downwards to an increasingly pessimistic worldview and existential vision, culminating in such technical-formal productions as Hi no tori [The phoenix, 1994, based on Tezuka Osamu's manga], Elisabeth: The rondo of love and death (Erizabēto: Ai to shi no rondo, 1996, based on Michael Kunze and Sylvester Levay's musical from 1992), The Phantom (Fantomu, 2004, based on Maury Yeston and Arthur Kopit's musical from 1991 inspired by Gaston Leroux' novel The Phantom of the Opera, 1910) or Gubijin [The beautiful Gu, 2010]. The few rays of hope and light in such performances as Kokkyō no nai chizu [The map without borders, 1995], Puraha no haru [The Spring in Prague, 2002] or Paradaisu purinsu [Paradise Prince, 2008] are unexpected exceptions in an ideological-aesthetic environment dominated by lack of enthusiasm and courage; here, identity is experienced momentarily and individually (Bauman 2001a: 35; Bauman 2001b: 74). Not only did the social, economic and political events in the dawn of the 1990s induce this general cultural apathy, but so did the gradual loss of centre in an anomic world and the disintegration of social structures. There are no more moral models, but charismatic stars embedded in breathtaking performances to symbolize the death of the ethics and the all-encompassing emergence of the aesthetics, so that the delight of imagination is replaced by the hegemony of ideology. While staging love as the catalyst of identity, Takarazuka Revue productions adapt to the new historical circumstances and hardly allow for illusions. They now reflect the needs and compulsions of a new era lacking centers or borders. The economic disaster and political discomfort, while confronting the international community, correspond to the socio-emotional conditions of disenchantment, dislocation, solitude and cultural confusion. Without attempting to ob- 
trusively display models to imitate or paths to follow, Takarazuka Revue-labeled blockbusters penetrate nowadays more than ever the public consciousness, domestic as well as overseas. This marketing strategy is a consequence of the Japanese fans' disappointment visible in decreasing sales figures and, in turn, calls for a basic reconsideration of Takarazuka Revue's position within the spectrum of Japanese modern culture - possibly as integral part of a larger world culture.

\subsection{The ideology of identity - the otokoyaku}

Throughout Takarazuka Revue's postwar history and its staging of identity, it was mainly the androgynously charismatic and ambivalent figure of otokoyaku that transported its ideals. However, compared to the apparently submissive and conformist musumeyaku, the otokoya$k u$ 's position suggests a strongly dialectical movement between traditional role models and innovative consumption patterns. To begin with, one recalls Kobayashi Ichizō's statement that audiences should desire the otokoyaku, but identify themselves with musumeyaku (Kobayashi 1955: 37). ${ }^{12}$ Furthermore, it was especially during the second stage, referred to previously as the transition or liquefaction stage, that current identificatory models became predominant, so that the objectivization of the otokoyaku as an entity of desire and site of projection - to use Julia Kristeva's (1974: 273) terminology - transformed the otokoyaku from a model of male presence into a mirror of female identity projections. Thus, every otokoyaku abandons the sphere of her own identity and accedes to the public space; she metamorphoses into a symbol for something which she cannot possibly be and she must obey the limits, rules and circumstances imposed upon her from the outside. Like Don Quixote in another spatial and temporal culture - who, in the second part of the novel meets persons having already read the first part of the novel, and who must be faithful to the book which he has himself become and protect it from misapprehensions, counterfeits and apocryphal continuations, to paraphrase Michel Foucault (1966: 73) - an otokoyaku must follow her own discourse and transform herself into an object of the process which she herself as a subject had originally created.

An important element in creating the otokoyaku as existential alternative is the otaku phenomenon regarded as emblematic for the socalled crisis of maleness in late modern, highly industrialized nations. In modern Japanese slang, an otaku describes an obsessive fan of different forms of subcultural models and fashions. Contrary to the established cliché, those described as otaku seem to have once been ambitious boys who were particularly affected by the loss of faith in science 
and technology in the 1970s, as Morikawa Kaichirō (2003: 86) observes. Takarazuka Revue's otokoyaku presents a credible counter-image to all current relativizing social and gender roles, positions as well as sexualities and identities. To the disempowered maleness represented by otaku, Takarazuka Revue's otokoyaku reacts with romantic maleness clinging to classical elements of male existence. As an ideal of the new male in female imagination, the otokoyaku ideologically embodies a male figure which, on a physical level, collects externally all the characteristics of male idols from Clark Gable to James Dean and Elvis Presley (strong bodies, compact attitudes, power and elegance) and possesses internally all kinds of positive qualities (composed, courteous, kind, considerate, faithful and brave). Such an amalgam penetrates Japanese characters as well, exemplified by Hikaru Genji in various productions or Sakamoto Ryōma (from Ishin-kaiten: Ryōma-den! [Sketches from the life of Sakamoto Ryōma], 2006). ${ }^{13}$ However, an otokoyaku may not simply contain all these characteristics like a statue, but she must show weakness along the course of her development and must reach the right decision at the right moment - even when this causes pain, according to the centuries-old samurai codex still present in the consciousness of most audiences (Etō et al. 2007: 184). As a blatant antagonism to the image of the otaku, which is by now omnipresent in Japan and from Japan spreading worldwide, the otokoyaku version of the male essence appears as a charismatic individual capable of abnegation and sacrifice, as fans repeatedly underline in their statements. The almost irrationally passionate José (from Carmen, 1946) will be replaced by the down-to-earth personality of Curly McLain (from Oklahoma! [Okurahoma!], 1967, based on Richard Rodgers and Oscar Hammerstein's musical from 1943) whose role, as a new model of male existence, is to provide material support and moral orientation to his fellows. Starting with Oscar François de Jarjayes (from The Rose of Versailles, 1974), one notices a division of otokoyaku figures.

On the one hand, there is a sensible enfeeblement of male ideals, inaugurated by Hans Axel von Fersen (Marie Antoinette's lover from The Rose of Versailles) and his inability to save his pride as well as his lover from the storms of destiny. On the other hand, Rhett Butler (from Gone with the Wind, 1976) is a pathetic character expressing the dissolution of identity borders and the declining definition of humanity in the consumer society: in spite of his aggressive maleness, he is unable to possess the woman he loves and is eventually compelled to give her up. There is an illusionary attempt in the 1980s at a last revitalization of male ideals in the figure of Bill Snibson (from Me and my Girl, 1987, based on the musical by Douglas Furber, L. Arthur Rose and Noel Gay from 1937); however, he is an import from prewar Great Britain 
with its artificially preserved aristocracy. The charismatic, extroverted Tóto [German: Tod], interpreted as a death god (shinigami) in the Takarazuka Revue adaptation Elisabeth: The rondo of love and death (1996) of the Vienna-premiere Elisabeth (1992), expresses the failure to reinforce clear ideals in the here and now, followed by the Shinto god of the sea and storm Susano-o (from the eponymous performance in 2004) who accentuates the crisis of the human being in the era of general liquefactions: of identity, of culture, and of gender (Grăjdian 2009: 274; see Bauman 2000: 131). Nevertheless, the employment of classical, archetypal characters as symbolized by Shirasu Jirō (from Reimei no kaze: Samurai-jentoruman Shirasu Jirō no chōsen [A morning breeze: The challenge of Jiro Shirasu, the samurai-gentleman], 2008), one of the most important businessmen in postwar Japan, means the acute re-actualization of the wakon yōsai [Japanese spirit, Western knowledge/technology] slogan which he embodies in his synthetic figure. Though educated at famous schools in England, Shirasu Jirō bares his soul for Japan's welfare and defies Douglas MacArthur with the words: "Japan has lost the war, but that doesn't mean Japan has been enslaved." He dashes like a "morning breeze" through the turbulent twentieth century, firmly determined to devote himself entirely to Japan's postwar reconstruction and to the restoration of its sovereignty.

Contrastingly, also starting with Oscar from The Rose of Versailles, there is the gradual empowerment of female figures impersonated by otokoyaku, and not by musumeyaku, as had been traditionally preassigned. Performed by an otokoyaku, Oscar herself is a girl raised and educated as a boy in order to inherit and protect the family's name and wealth. Oscar's failure to define his/her own identity in the tumult of history would be continued by Scarlett O'Hara (from Gone with the Wind, 1976) symbolizing the strong, self-made woman of modernity and her overwhelming energy which erases prejudices, contradictions and obstacles (Kawasaki 1999: 81). Scarlett O'Hara is a crucial moment in Takarazuka Revue's endeavors to define gender and identity: she struggles for the continuity of family and history, but her struggle itself is a negation of traditionally transmitted family and history. Her inner misconception transforms Scarlett O'Hara into a tragic figure unable to attain her ideals and breaking down under their weight. Beyond the materialistic Jacqueline Carstone (from Me and my Girl, 1987), Aida (from Ōke ni sasagu uta [A song for kingdoms], 2003, based on Giuseppe Verdi's opera Aida, 1871) represents Takarazuka Revue's attempt - and failure - to reinforce clear models: Aida is caught between her love for Radames, who had attacked her country, and her patriotism; her decision to obey her father's orders to save her home- 
land and, in doing so, to betray Radames and her love for him leads to a catastrophe culminating in the death of all those involved.

Independently if an otokoyaku impersonates a male or a female character, her dualism reveals the impossibility of following classical rules of behavior and identification. Between Shirasu Jirō and Aida, there is the ambivalence of a strong belief in traditional ideals: basically, otokoyaku as ideological model and embodiment of self-styled identity confirms the fact that the otaku phenomenon points out, on a social level, the identity confusion in postwar Japan (Morikawa 2003: 71). The otaku is the individual replication of the historically accomplished transition from premodernity to postmodernity without a sufficient modernization. The otaku culture is marked by the conscious abandonment of message and focus on media through the projection of one's own emotion upon two-dimensional, symbolic simulacra constituted by separate elements contained in databases, as Azuma Hiroki (1999: 33) puts it. Otaku's reality is the reality of his own hand-crafted metaphorical work, not the reality of general society. It is indeed a romantic, friendly metaphorical work softly melting fantasy and substantiality into one. Takarazuka Revue's otokoyaku as desire object and projection site transforms the otaku cliché into a hero. The otokoyaku reacts with the reinforcement of her position as a mirror of the self and a window to the other while internalizing her position as a female impersonator of male figures; in doing so, the otokoyaku metamorphoses into a figure of longing and, paradoxically, belonging.

\subsection{The aesthetics of identity - the musumeyaku}

The musumeyaku in her aestheticization of identity patterns strikes, for once, as the stylized concretization of the shojo concept: it is the tolerated competence to fulfill and to represent oneself - although simultaneously questioned through the cute appearance. Literally, shojo means "young unmarried woman"; as concept and social phenomenon, the shojo has emerged since the late 1960s in Japan in the historical context of female empowerment as a consumerist phenomenon, and has become emblematically famous in the West as "girl power" since the mid1990s (Ōtsuka 1991: 26). ${ }^{14}$ While individualism and aggressiveness seem the main characteristics of the phenomenon in the West, the ambivalent shöjo figure as an exponent of "girl power" in Japan undermines the generality of cultural and discursive minimal pairs such as male-female, Western-Japanese, innovation-tradition, mass-elite and individual-collective. The shöjo's most paradigmatic concretization is the Takarasienne and, as such, decidedly the musumeyaku and not the otokoyaku. Though Kobayashi Ichizō was no feminist and feminist 
movements were, for him, devious, he was aware of the power of the female instance in Japanese culture (Tsuganesawa 1991: 44). Thus, the cultural stylization of Japaneseness in late modernity as shojo and its transformation into an identity paradigm through the instrumentalization of the Takarasienne gains clear contours. The shojo as musumeyaku can represent herself; she is free, due to her exclusion from all active sectors of public life. As an outsider, she doesn't obey the usual rules dictating roles and behavior patterns - like marriage, for instance. To shöjo, marriage means limitation through maturation - in her case, there is no question of moratorium or a Peter Pan complex or the fear of entering the grown-ups' world, but rather, there is a deeply conscious refusal to do so. In refusing the grown-ups' world, the shojo attempts to stay active, powerful and self-determining (Ōtsuka 1991: 112). In contrast to the shojo image in other fields of popular culture such as anime or manga, the Takarazuka Revue's shojo is powerful and self-confident without being sexually objectified and without losing her humanity in the empowerment process, by metamorphosing into a monster or a cyborg (see Haraway 1991: 75-79). The simultaneous exhibition of power and cuteness in Takarazuka Revue's shōjo figure relates to her simultaneous consumerist and self-stylizing roles as two sides of the same coin: the shojo-musumeyaku answers with open femininity instead of aggressive sexuality - as is sometimes the case in anime or manga - and behaves according to her own rules within the crumbling patriarchal system. Herein lies the reason why the shojo as embodied by the musumeyaku in Takarazuka Revue may seem strong, but not so strong so that her femininity breaks down. Basically, she must feature the traces of her future motherhood - and this is where her definitive power hides, in contrast to the traditional and conventional image (in the West as well as in Japan) that motherhood and sexual satisfaction equal disempowerment.

Musumeyaku's cuteness and submission as a female identity ideal could be interpreted as a crisis of femininity in late modernity corresponding to the previously mentioned crisis of masculinity in postwar Japan and spreading worldwide. As precursor of socio-cultural phenomena, Takarazuka Revue strove to design a fresh femininity ideal backed by traditional concepts embodied in the musumeyaku: dignified submission, intelligent discretion, physical beauty and moral purity. Musumeyaku were supposed to be a reflection of male desire and, as such, more of a remembrance in the male memory than an active presence (Kawasaki 2005: 18). However, the performance practice transformed otokoyaku's cool reticence and musumeyaku's cute submission into behavior models and identification ideals without including resistance as an alternative existential model. Until Marie Antoinette (from 
The Rose of Versailles, 1974), female characters followed the classical pattern of supporting their male counterparts. The Rose of Versailles presented, for the first time in Takarazuka Revue's performance history, a forbidden love story, doomed to fail due to social and historical hindrances. Marie Antoinette's execution - the execution scene is, in itself, a milestone in the history of the aestheticization of reality would represent a crucial moment in the ideological turnover of moral ideals (Ishii et al. 1996: 28-31). Thereupon, Melanie Hamilton (from Gone with the Wind, 1976) unconsciously supports and leads her weak, though charming, husband Ashley Wilkes, but her premature death leaves him in a state of complete prostration, unable to continue living by himself. The transition from this motherly female figure, incapable yet of developing herself and protecting those around her, into a selfconfident, egoistic and self-centered person would be attained in the figure of Elisabeth (in Elisabeth: The Rondo of love and death, 1996) who, as cult-empress Sisi, derives her power and charisma from the rejection of traditional images and roles and defies both her husband, emperor Franz Joseph, and Tōto (i.e., death) while determining her destiny and status. However, her incompetence at saving her own son from suicide in spite of her political visionarism transforms her into a pathetic figure; successful fulfilling of state-relevant attributions does not compensate for her failure to accomplish basic motherly tasks which are - the audience is indirectly told - the real function of a woman (Kawasaki 1999: 142). This return to the ryōsai kenbo [good wife, wise mother] ideal, while staging Western performances, continues with Christine's character (from The Phantom, 2004); here the lover is patterned upon the image of a deceased mother. Still, Erik's obsession with superimposing these two beloved appearances - his own memories of his deceased mother and the real extant figure of a beloved woman - hinders Christine's efforts to drag him out of his world of darkness and hatred and leads ultimately to her failure to save him - and to his death. This process of staging the inability of female individuals to support and save a beloved partner would eventually reach an end point in Gubijin's character (from the eponymous restaging of the 1951 performance in 2010) where Gubijin prefers to kill herself when there is only slavery left as a possibility, thus compelling Kō U (aka Xiang Yu) to accept his defeat and to commit suicide as well. The loss of faith - in self and in others - seems to be a crucial standpoint in a world where the dissolution of centers and the enlargement of borders induce the effacement of individual actors within masses.

The enfeeblement of the female characters as interpreted by musumeyaku compensates for the empowerment of female characters per- 
formed by otokoyaku. Gradually, musumeyaku female characters would metamorphose into bare decoration, lacking their own will, ideas or personality. However, in combination with the otokoyaku female characters, the musumeyaku would develop, propagate and implement a new form of shojo to compete with the insufficiency of ideological models and aesthetic credos in late modern Japan: the shojo ideal as staged by the Takarasienne is simultaneously anti and pro establishment (Ötsuka 1991: 184). Her ideological ambivalence relates to the potentially subversive plots and conformist solutions. In an increasingly disenchanted world, the possibility became obvious that musumeyaku could represent an emotional ideal to using her own feelings as engine of self-fulfillment. This is a very important switch which confers women as potential mothers and educators a previously underestimated power most evident in musumeyaku's discreet elegance and composed submission, the Takarazuka Revue-like - and by extension: the Japanese - versions of Meinhard Miegel's (2007: 29) new forms of "assiduity and modesty" (Flei $\beta$ und Bescheidenheit) as basic principles of an innovative, future oriented interaction with the middle-class ideals.

\section{Conclusion: Towards a new paradigm of identity}

I started this paper by stating that Japan is redefining superpower as a cultural issue. In the light of its findings, I should reformulate this statement by adding that Japan is redefining superpower through the reinvention of humanity as a transcendent endeavor and an orchestration of tenderness as an emergent identity paradigm. Otokoyaku is an ideological construction mirroring female desires and expectations - and as such, is an illusionary identity which can never be attained. Fans' fulfillment in the imaginary world should confirm otokoyaku's magic, and yet place them on the musumeyaku's level (Kawasaki 2005: 105108). The emergence of a new identity paradigm based on tenderness (yasashisa) calls for a fresh, dynamic manipulation of middle-class ideals through the restructuring of emotional values; simultaneously, the fundamental reconsideration of Takarazuka Revue's position within the spectrum of Japanese modern culture as a possibly integral part of a larger world culture rests upon its administrators' awareness that incorporative isolation is no alternative to indiscriminate internationalization. This dialectic handling of the self and of the other requires, according to the existential model promoted by Takarazuka Revue, a re-evaluation of humanity, not as a competitive undertaking, but as a playful togetherness. In recent performances, the overcoming of a capitalist human ideal ("[someone] who is prudently restrained in the office and wildly anarchic in the shopping mall", Eagleton 2003: 28) and the 
turning of the spotlight towards more normative concerns like the integration of the individual within the community, the importance of the family, the nostalgic depiction of one's homeland, the enhancement of money and career as a means of making a living and not as an ultimate existential goal, and the moderate patriotism - however arguable they might be elsewhere - gradually led to the formulation of a re-solidified identity paradigm as self-reflexive project to harmoniously unify lucidity and compassion, courage and perseverance, sincerity and respect: this seems to be the core structure of the homo tener, the tender human, calling for a (more) affectionate relationship with the self and the other.

The starting point of this analysis was the assumption of Takarazuka Revue's ability to reflect and convert the socio-cultural tendencies of postwar Japan. As a self-proclaimed mirror of the Japanese world, Takarazuka Revue absorbs the current historical tendencies in Japan and transforms them artistically; on the basis of Takarazuka Revue's sketched stages of postwar Japanese culture as well as on its ideological and aesthetic achievements, further forms of canonically accredited mass industries - such as anime, manga, video games, fashion, J-Pop music, SUPERFLAT art and design - generate, propagate and implement new identity paradigms similar to Takarazuka Revue's original model (see Murakami 2000: 11-12). In turn, Takarazuka Revue takes over the current tendencies of Japanese society which had been previously molded by renowned mass industries and it develops them artistically, only to be subsequently perpetuated by other forms of Japanese contemporary culture. This appears as an endless, spiral-like process. The arrival point of this analysis seems to be the issue that tenderness as promoted by Takarazuka Revue emerges as the ideological and aesthetic core of a re-solidified identity paradigm, to be adopted, reproduced and perpetuated by approved mass-media.

Indifferent as to whether the world described as "a comedy to those who think and a tragedy to those who feel" (in a letter from Horace Walpole to Sir Horace Mann, 1769, quoted in Bauman 2001b: 54) moves towards its self-orchestrated destruction, Takarazuka Revue stubbornly continues designing identity patterns as aesthetic-ideological formulations and concretizations of tenderness in its performances and its public exposures. Thus, tenderness as an answer to hatred and war becomes the Japanese contribution to worldwide altercations. Through tenderness as an existential attitude one could re-discover one's own humanity due to a soft(er) interaction with the self and the others; the re-discovery of this lost or forgotten humanity might lead to the regaining of control over one's own life, in opposition to George Orwell's 1984 or Aldous Huxley's Brave New World (see Bauman 
2001b: 97). During the last two to three years, tenderness configures as the symbolic core of a new, re-solidified identity paradigm both in Takarazuka Revue's performance practice and in its marketing strategies, leading to the development of fresh life patterns. It is a progressive return to the creatively loaded early 1930s when Kobayashi Ichizō compiled and introduced the Takarazuka Revue motto "Kiyoku, tadashiku, utsukushiku" as existential slogan. If, as culturally presented in Takarazuka Revue's productions recently, discreet elegance and composed submission become the new social paradigms, then responsibility and courage, assiduity and modesty become the political-economic paradigms implementing the Japanese solution as a life model; balanced by nostalgia as an emotional layer, these existential patterns conditioned by tenderness are the catalyst of cultural revitalization and the basic principles of a liberal, optimist regeneration of middle-class aspirations (see Miegel 2007: 189). Ultimately, Takarazuka Revue reinforces tenderness emerging from the rightful handling of compassion and hope, lucidity and perseverance as a solution to current problems and misunderstandings within the international community, a correct manipulation of love that can propagate and implement peace, prosperity and happiness. However, the Japaneseness of such solutions is less stressed in the plots and in the construction of the characters of recent performances; rather, the universality of these aspirations and the necessity of a stable identity paradigm in clear historical contexts seem the main issues displayed on-stage and in the marketing campaigns carried out publicly. Beyond its stylistic cacophony, ideological inconsistency and aesthetic contradictions, Takarazuka Revue blossoms out incessantly as a romantic world - and first of all, as a world full of longing for romantics. As a dynamic alternative to the modern Japanese everyday life, which is infused with Western influences, dominated by consumerism, suffocated by excess and surplus, Takarazuka Revue offers through the overwhelming display of these parameters - the Western-like appearance of the actresses, consumption-driving marketing strategies, excess and surplus celebrating performance practice - the model of a rigorous, disciplined lifestyle as a means to experience fulfillment focused on important tasks. This model is concretized in the slender, fragile, shy Takarasienne attempting a parallel option to the otaku figure and highlighting the shōjo figure as a positive, dialectical, still clearly outlined entity.

In the process of identity stylization in contemporary Japan, the Takarasienne appears simultaneously as the essence of the Japaneseness and as a chaos-driving force within the traditional patriarchal order in spite of her traditional, familist education, due to the powerful symbols she is loaded with. However, for the creation of a singular, univocal, 
autonomous identity paradigm compatible with late-modern challenges, such a disturbing instance is inevitable. The disorder permanently insinuated by the Takarasienne in the tension between otokoyaku and musumeyaku mirrors the instability and ambiguity of the Japanese modernity as a reputed monolith. Eventually, almost 100 years after its foundation, Takarazuka Revue seems to have become what its founder Kobayashi Ichizō dreamed of: the self-conscious icon of modern Japan, a unique synthesis of Japanese spirit and Western technology/knowledge, emblematically embodied by the ambivalent, fascinating and mysterious figure of the Takarasienne.

Maria Grăjdian (maria.grajdian@ce.citizen.co.jp) holds a Ph.D. in ethnomusicology from Hannover University of Music and Drama, Germany. Her research focuses on Japanese contemporary culture (Takarazuka Revue, anime, music, SUPERFLAT), the history of knowledge (encyclopedias) and the dynamics of identity in late modernity. Recent publications include a number of research articles in academic journals as well as books on contemporary Japanese culture such as Flüssige Identität: Die postmoderne Liebe, die Takarazuka Revue und die Suche nach einer neuen Aufklärung (2009) and Takahata Isao (in German, 2010).

\section{Notes}

1. "Superpower" is referred to as a nation-state able to propagate and protect its own interests on a transnational level within the increasing multilateral interdependence between nation-states at the turn of the millennium - via cultural assets (Castells 1997: 262-269; see also McGray 2002: 45).

2. "Cultural imperialism" refers here to the process by which nation-specific cultural elements and structures are propagated and implemented via cultural assets in and outside the geographical borders of that very nation. The basic difference between this and classical soft power endeavors consists of the stress on culture, and not on nation, which is in contrast to Japanese wartime (cultural) imperialism.

3. In a basic assumption, love is to be regarded as a catalyst of "rites of passage" (Willem van Gennep/Victor Turner) and as a foundation of human existence. Love guides initiation trips for overcoming the self and liberation from one's own, self-inflicted immaturity through the separation from the real world, and temporary admittance within a liminal space before being accepted in a new order (Grăjdian 2009: 33; see Turner 1968: 72).

4. According to the prevalent terminology, the otokoyaku could also be called "male impersonator" as a counterpart to the description "female impersonator" often used when a male actor is impersonating a female (e.g., the onnagata in Kabuki), but the formulation "female interpreters of male roles" in otokoyaku's case might be clearer in this context.

5. In the following lines, I use the word "actress" to refer generally to Takarazuka Revue performers. The Japanese word used in the Takarazuka Revue specific 
terminology is seito, usually translated as "pupil" or "student"; the employment of the seito notion to describe the Takarazuka Revue actresses alludes to the fact that, while active in the Takarazuka Revue enterprise and on its stage, the actresses' status is equals to beginners in the traditional order - a status which they can only overcome when they finish their career as Takarasiennes and enter the "real world" of the grown-ups (Ueda 1976: 37). Takarasienne is another name for Takarazuka Revue actresses introduced by the director Shirai Tetsuzō who compared the cute Takarazuka Revue actresses with the beautiful Parisiennes at the Moulin Rouge (Hashimoto 1999: 11).

6. I use ideology as referred to by Terry Eagleton and further enriched by Slavoj Žižek: the fetishization of the logos - that is, of the language and of the ideas behind the words - to the disadvantage of the practical, quotidian dimension of life (Eagleton 1990: 16; Žižek 1989: 78).

7. I refer to the term aesthetics as employed by Terry Eagleton and later completed by Gernot Böhme. In this reading, aesthetics connects less to beauty as an abstract, independent principle, but as a perception and processing of that very beauty as expressed in the concept of atmosphere (Böhme 1995: 35-47; Eagleton 1990: 19).

8. Kobayashi Ichizō (1873-1957), Japanese industrialist and politician, was one of the most influential and progressive entrepreneurs in prewar Japan. He is best known as the founder of the Hankyū Railways Company in 1907 with its main terminal at Umeda station in Osaka and for his successful development of the railway infrastructure in an adverse region in the northern part of Kansai (WestJapan) through the implementation of residential areas along the railway line, an amusement park, a department store at the railway terminal as well as, in time, the main attraction: the Takarazuka Grand Theater in Takarazuka (Iwahori 1972: 47; Watanabe 1999: 39).

9. While it is true that Japanese popular culture - especially anime and manga abounds with dark, depressing, even psychotically tinged visions, fans and experts repeatedly mentioned the subliminally omnipresent message of "love, hope and trust" transported by Japanese subcultural products (see Drazen 2003: 36).

10. Especially Tezuka Osamu's works, in which this aesthetics predominates, functioned as the main means of propagating and implementing the "long legs and big eyes" beauty ideal in the Japanese everyday life. I argue that besides his undeniable affinity to American animation (Walt Disney, Max Fleischer), it was rather the pre-existence of this aesthetic in the Japanese cultural environment, specifically represented by the strong popularity level that Takarazuka Revue had already attained, that induced Tezuka Osamu - a declared fan of Takarazuka Revue - to take this aesthetic over and transform it into a national hallmark.

11. The Takarazuka Revue theatre in Tokyo stayed closed until 1955 while being used as an entertainment center by the occupying American troops (Robertson 1998: 182).

12. Though Kobayashi's original intention was to develop Takarazuka Revue into an entertainment place for the whole family, the audiences, intriguingly enough, eventually became $95 \%$ female (Hashimoto 1999: 29).

13. The fact that approximately two-thirds of the performances are Western-influenced and one-third refers to Asian sources is in particular reflected in the costumes and scenery designs, but the characters' inner and outer configuration stays basically unchanged: their ethnical affiliation and historical contextualization are to be extracted from the plot and the audience's background expectations rather than from the obvious stage representation and public commercialization. 
14. The shōjo meaning "girl" as a delimited social group emerged at the dawn of the 20th century in Japan; a range of shojo magazines aiming mostly at educational goals via comic strips were published as early as 1902 Shöjo-kai [Girls' world], 1906 Shōjo sekai [Girls' world] and 1908 Shōjo no tomo [Girls' friend]. As WWII progressed, magazines containing comics, and especially those referring to shōjo readership, perhaps regarded as frivolous, began to disappear. (Takarazuka Revue itself was called between 1919 and 1940 Takarazuka Shōjo Kageki[dan]: Takarazuka Girls Revue [Company].) In the postwar era, the shōjo concept underwent an abrupt revitalization followed by a spectacular re-semantization process in domestic subcultures, in the course of which it was loaded with the current meaning of "liberated, empowered young unmarried woman." The shojo was originally represented in anime and manga works and subsequently migrated to other fields of (popular) culture(s) (see Schodt 1986: 32). In this paper, I refer exclusively to the postwar semantic sphere of the shojo, unless otherwise noted.

\section{References}

Anderson, Perry. 1988. The origins of postmodernity. London: Verso.

Azuma, Hiroki. 1999. Yübinteki fuantachi [Postal incertitudes]. Tokyo: Asahi Shimbun.

Bauman, Zygmunt. 2000. Liquid modernity. Cambridge: Polity.

Bauman, Zygmunt. 2001a. Community: Seeking safety in an insecure world. Cambridge: Polity.

Bauman, Zygmunt. 2001b. The individualized society. Cambridge: Polity.

Berlin, Zeke. 1988. Takarazuka: A history and descriptive analysis of the all-female Japanese performance company. Ann Arbor, Michigan: University Microfilms International.

Böhme, Gernot. 1995. Atmosphäre: Essays zur neuen Ästhetik. Frankfurt on the Main: Suhrkamp.

Böhme, Gernot. 2001. Ästhetik: Vorlesungen über Ästhetik als allgemeine Wahrnehmungslehre. Munich: Wilhelm Fink.

Castells, Manuel: 1997. The information age: Economy, society and culture. Volume II: The power of identity. Cambridge, MA \& Oxford, UK: Blackwell.

Castells, Manuel. 1998. The information age: Economy, society and culture. Volume III: End of millennium. Cambridge, MA \& Oxford, UK: Blackwell.

Drazen, Patrick. 2003. Anime explosion! - The what? why? \& wow! of Japanese animation. Berkeley: Stone Bridge.

Eagleton, Terry. 1990. The ideology of the aesthetic. Oxford, UK \& Cambridge, MA: Blackwell.

Eagleton, Terry. 2003. After theory. New York: Basic Books.

Etō, Shigehiro, Tomoko Ueki, Akiko Katō, Reiko Shimizu \& Kaoru Hyūga. 2007. Takarazuka Kagekidan sutadīzu: Butai o 100-bai tanoshimu chitekina 15 kōza [The Takarazuka Revue studies: 15 intellectual lectures to enjoy the stage 100 times]. Tokyo: Ebisu Kōshō.

Foucault, Michel. 1966. Les mots et les choses: Une archéologie des sciences humaines. Paris: Gallimard.

Grăjdian, Maria. 2009. Flüssige Identität: Die postmoderne Liebe, die Takarazuka Revue und die Suche nach einer neuen Aufklärung. Bucharest: National Music University.

Haraway, Donna. 1991. Simians, cyborgs, and women: The reinvention of nature. New York: Routledge. 
Hashimoto, Masao. 1999. Subarashii Takarazuka Kageki - Yume to roman no 85toshi [The wonderful Takarazuka Revue: 85 years of dreams and romance]. Takarazuka: Takarazuka Kagekidan.

Hendry, Joy. 2000. The orient strikes back - A global view of cultural display. Oxford \& New York: Berg.

Ishii, Tetsuya, Yūko Arakawa, Kaoru Kitami, Mari Takahashi. 1996. Takarazuka Akademia 1: Ueda Shinji no sekai [Takarazuka Academy 1: Ueda Shinji's world]. Tokyo: Seikyūsha.

Iwahori, Yasumitsu. 1972. Isai Kobayashi Ichizō no shōhō: Sono taishū shikō no rejā keiei shuhō [The special business strategy of the genial Kobayashi Ichizō: His masses-oriented leisure enterprise methods]. Tokyo: Hyōgensha.

Kawasaki, Kenko. 1999. Takarazuka - shōhi shakai no supekutakuru [Takarazuka the spectacle of the consumption society]. Tokyo: Kōdansha.

Kawasaki, Kenko. 2005. Takarazuka to iu yütopia [The utopia called Takarazuka]. Tokyo: Iwanami Shoten.

Kobayashi, Ichizō. 1955. Takarazuka manpitsu [Takarazuka miscellanea]. Tokyo: Jitsugyō no Nihonsha.

Kristeva, Julia. 1974. La révolution du langage poétique. Paris: Seuil.

McGray, Douglas. 2002. Japan's gross national cool. Foreign Policy (May/June 2002). 44-54.

Miegel, Meinhard. 2007. Epochenwende: Gewinnt der Westen die Zukunft? Berlin: Ullstein.

Morikawa, Kaichirō. 2003. Shuto no tanjō: Moeru toshi Akihabara [Learning from Akihabara: The birth of a personapolis]. Tokyo: Gentōsha.

Murakami, Takashi. 2000. SUPERFLAT. Tokyo: Madora Shuppansha.

Ōtsuka, Eiji. 1991. Shōjo minzokugaku [The shōjo ethnography]. Tokyo: Kōbunsha.

Robertson, Jennifer Ellen. 1998. Takarazuka: Sexual politics and popular culture in modern Japan. Berkeley: University of California Press.

Saitō, Jirō. 1996. "Shōnen janpu" no jidai [The "Shonen Jump" era]. Tokyo: Iwanami Shoten.

Schodt, Frederick. 1986. Manga! Manga! Manga! The world of Japanese comics. New York: Kōdansha.

Stickland, Leonie. 2008. Gender gymnastics: Performing and consuming Japan's Takarazuka Revue. Melbourne: Trans Pacific.

Tsuganesawa, Toshihiro. 1991. Takarazuka Kageki senryaku: Kobayashi Ichizō no seikatsu-bunkaron [The Takarazuka Revue strategy: Kobayashi Ichizō's existence culturology]. Tokyo: Kōdansha.

Turner, Victor. 1968. The ritual process: Structure and anti-structure. Harmondsworth: Penguin.

Ueda, Shinji. 1997. Takarazuka, waga Takarazuka [Takarazuka, my Takarazuka]. Tokyo: Hakusuisha.

Ueda, Yoshitsugu. 1976. Takarazuka ongaku gakkō [The Takarazuka music academy]. Osaka: Yomiuri-Life.

Watanabe, Hiroshi. 1999. Takarazuka Kageki no hen'yō to Nihon kindai [Takarazuka Revue's metamorphose and the Japanese modernity]. Tokyo: Shinshokan.

Žižek, Slavoj. 1989. The sublime object of ideology. London \& New York: Verso. 